\title{
Alberto Guerreiro Ramos na UFSC
}

\section{Flávio da Cruz}

Universidade Federal de Santa Catarina (aposentado) E-mail: flacruz2012@gmail.com

Tos anos de 1980 e 1981, como contador do Serviço Público Fedepois na década anterior havia trabalhado como professor no ensino fundamental e do ensino médio, eu tinha como sonho frequentar um mestrado para tentar um concurso de professor universitário. Outra inquietude era com a situação dos negros na cidade de Florianópolis e a relativa timidez dos movimentos de representação dessa base étnica, na qual tentava me firmar como militante.

Quando soube da abertura de inscrições para a especialização, fiz as entrevistas e passei a frequentá-la, no nível de pós-graduação como preparatórios para o mestrado. O primeiro foi na área de Recursos Humanos no CFH/UFSC. O outro curso de especialização presencial, como preparação para o mestrado de Administração Pública na UFSC no Centro de Ciências da Administração, que ocorreu na ESAG/UDESC e na área de administração.

Neste último, conheci parte da obra do sociólogo Alberto Guerreiro Ramos, numa disciplina ministrada pelo Professor João Benjamin da Cruz Júnior, que tinha vínculo com as duas Instituições.

João Benjamin tinha feito o doutorado nos Estados Unidos e lá fora aluno de Guerreiro Ramos. Na época, o livro em destaque era a obra intitulada: "A Nova Ciência das Organizações: uma reconceituação da riqueza das nações". Esse livro foi editado na Fundação Getúlio Vargas, tratava-se de uma tradução do "The new Science of Organization", que havia sido lançado, originalmente, nos Estados Unidos. 
Após uma das aulas do Professor Benjamin, fomos ao evento e, nesse evento, além da recepção que ele e o Professor Ubiratan Simões de Rezende da UFSC e do Mestrado em Administração Pública ofereceram para o ilustre sociólogo, haveria a possibilidade de se obter alguns autógrafos. Eles se conheciam do doutorado realizado numa das Universidades dos Estados Unidos e Alberto Guerreiro Ramos estava lecionando no mestrado da UFSC.

Na época, eu estava dando meus primeiros passos no movimento negro local e aqui em Florianópolis era um tabu a militância nas ruas, em praças ou em locais de amplo acesso da população. Havia convivido com fortes experiências no enfrentamento do preconceito racial na minha cidade natal, Santo Amaro da Imperatriz, onde pela proximidade com a música e com a arte, minha família tinha experiência na superação de espaços e no mais, eu respondia como podia.

No início da recepção, houve um pedido do sociólogo para que o Professor Ubiratan dedilhasse um violão e tocasse alguma coisa da música popular brasileira para o homenageado. Ninguém tinha o instrumento e nesse momento, me lembrei de que minhas irmãs, moradoras de uma pensão de estudantes na Rua Bocaiúva, não me negariam um empréstimo.

Vislumbrei uma forma de suprir tal falta, peguei meu Passat e fui buscar o dito cujo violão. Rapidamente, voltei com o violão debaixo do braço e todos pensaram que eu tocaria alguma coisa. Passei o violão para o Professor Ubiratan, pois os meus irmãos e irmãs é que são artistas e nessa área eu não atuava.

Aparentemente, eu era o único negro no grupo. Além disso, tinha providenciado o violão. Portanto, fui bem recebido e então me aproximei para conversar com o sociólogo, numa das brechas de tempo ante a demanda contínua dos presentes.

Expus alguns dos planos que tinha para exercer uma militância no movimento negro: denúncias com provas e boletim de ocorrência baseado na Lei Afonso Arinos; conscientização e difusão associada com sensibilização na periferia (de modo que pudesse ser atraente para os moradores). No centro da cidade pensava na panfletagem. Basicamente, tencionava utilizar a música e outras manifestações ar- 
tísticas dos próprios negros da área e de fora para formar a aglutinação quantitativa, a que fosse possível e nos horários vagos.

Entendia que as práticas de conscientização fincadas numa linguagem acadêmica e dependentes de apoio da imprensa local eram morosas, manipuláveis e distantes da maioria dos negros e negras locais. Então, o plano era reunir e mesclar aspectos da conscientização com algo atraente e aglutinador até ir conquistando adeptos para a causa.

Fiquei encantado com o sociólogo, porque ele ouviu atentamente meus planos e me questionou porque eu estava demorando tanto para cair na luta e seguir para a prática. Eu não tive resposta: apenas olhei envergonhado, como se tivesse pedindo perdão pela omissão. Acho que, apesar disso, ele viu sinceridade no meu plano e confiou na proposta.

Não foi presunção ou egoísmo. De fato, no momento em que os presentes puderam obter o autógrafo tive outra surpresa, pois o sociólogo escreveu: "Ao Flávio, doido, sábio, mágico com os meus melhores votos. Guerreiro Ramos, SC, 17/6/81".

Mais tarde, entre 1985 e 1988, coloquei em prática parte do plano e acredito ter conseguido mobilizar boa parte das entidades representativas dos afro-descendentes residentes em Santa Catarina. De fato, e de direito, atuei na presidência da Comissão Catarinense do Resgate da Cultura Negra. Também participei do Grupo da UFSC no Centenário da Abolição da Escravatura e editei, em coautoria com outros militantes, duas cartilhas: "As Leis da Abolição" (6.000 exemplares) e "África: um Continente em Crise" (1.000 exemplares).

Quanto ao plano, acredito ter colocado em prática, inclusive aqui na UFSC, pois a fila do RU que eu aproveitava como espaço para as apresentações artísticas associadas com a conscientização. Sobretudo, com o Projeto Semana Afro-catarinense tenho a impressão de ter contribuído para interligar o movimento negro da capital com as cidades de Criciúma, Itajaí, Tubarão, Joinville e Lages, adotando parte do "puxão de orelha" recebido do sociólogo. 


\section{Flávio da Cruz}

Possui graduação em Ciências Contábeis pela Universidade Federal de Santa Catarina (UFSC), Florianópolis (1971), mestrado em Administração Pública pela Universidade Federal de Santa Catarina (UFSC)em 1986. Professor Titular no Departamento de Ciências Contábeis na Universidade Federal de Santa Catarina e ex-profes-

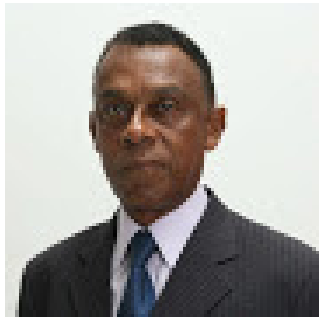
sor da ESAG-UDESC. Autor dos livros "Auditoria governamental" e "Contabilidade e Movimentação Patrimonial do Setor Público" entre outros e Membro da Academia Brasileira e Catarinense de Ciências Contábeis. Atua nas áreas de Administração Pública, Ciências contábeis e Contabilidade do setor estatal brasileiro.

\section{Livros Publicados:}

ATHAYDE, Autragésilo de; ALVES, Henrique L; ALVES, Uelinton Farias (Org.); CRUZ, Flávio da; CRUZ e SOUZA, Dina Teresa; TANGERINI, Nelson; VIEIRA DA SILVA FILHO, Osvaldo. Reencontro com Cruz e Souza. Florianópolis: Papa Livro, 1990.

CRUZ, Flávio da (Org.); GONZAGA, Maria de Lourdes da Costa; SILVA Francisco Libânio; VIEIRA DA SILVA FILHO, Osvaldo. As Leis da Abolição. Florianópolis: Projeto Semana Afro-Catarinense, 1987.

CRUZ, Flávio da. (Org.); KOFI Nydevu Awoonor. 1988: África: continente em crise Florianópolis: Projeto Semana Afro-Catarinense, 1988.

CRUZ, Flávio da (Org.); GLOCK, José Osvaldo; HERZMANN, Nélio; TREMEL, Rosangela; VICCARI JUNIOR, Adauto. Lei de Responsabilidade Fiscal Comentada. São Paulo: Atlas, (2000 a 2014) nove edições.

CRUZ, Flávio da (Org.); BARBOSA, Rui Rogério Naschenweng; GLOCK, José Osvaldo; HERZMANN, Nélio; VICCARI JUNIOR, Adauto. Comentários à Lei $N^{\circ}$. 4.320. São Paulo: Atlas, ( 1999 a 2008) cinco edições.

CRUZ, Flávio da (Org.); GLOCK, José Osvaldo. Controle Interno nos Municípios. São Paulo: Atlas, (2003 a 2006) duas edições.

CRUZ, Flávio da. Auditoria Governamental. São Paulo: Atlas, (1997 a 2008) três edições. 
Depoimentos

CRUZ, Flávio da. Auditoria e Controladoria. Programa Nacional de Formação em Administração Pública. Florianópolis: UFSC/CSE/CAD e UAB, (2012 a 2014) duas edições.

Recebido em 20/10/2015

Aceito em 16/12/2015 